\title{
Importance of Fc-mediated functions of anti-HIV-1 broadly neutralizing antibodies
}

\author{
Matthew S. Parsons ${ }^{1 *}$, Amy W. Chung ${ }^{1}$ and Stephen J. Kent ${ }^{1,2,3^{*}}$
}

\begin{abstract}
Anti-HIV-1 broadly neutralizing antibodies (BnAbs) exhibit an impressive capacity to protect against chimeric SIVHIV (SHIV) challenges in macaques and potently reduce viremia in both SHIV-infected macaques and HIV-1-infected humans. There is a body of evidence suggesting Fc-mediated functions of anti-HIV-1 binding antibodies are important in protecting from infection and controlling viremia. The degree to which the efficacy of BnAbs is assisted by Fc-mediated functions is of great interest. Challenge experiments with the older generation BnAb b12 showed that mutating the Fc region to abrogate Fcy receptor binding reduced protective efficacy in macaques. Similar data have been generated with newer BnAbs using murine models of HIV-1. In addition, the degree to which therapeutically administered BnAbs reduce viremia suggests that elimination of infected cells through Fc-mediated functions may contribute to their efficacy. Fc-mediated functions that eliminate infected cells may be particularly important for challenge systems involving cell-associated virus. Herein we review data regarding the importance of Fc-mediated functions of BnAbs in mediating protective immunity and control of viremia.
\end{abstract}

Keywords: HIV-1, ADCC, Broadly neutralizing antibodies

\section{Introduction}

An HIV-1 vaccine is urgently needed, and new technologies to control HIV-1 infection in the absence of lifelong antiretroviral drug therapy are being actively pursued. Many highly potent neutralizing antibodies that neutralize broad arrays of HIV-1 isolates, termed broadly neutralizing antibodies (BnAbs), have been isolated in recent years [1]. Passive transfer of these antibodies reliably protects macaques from exposure to cell free chimeric Simian-Human Immunodeficiency Virus (SHIV) and reduces viremia in SHIV-infected macaques and HIV-1-infected humans [2-12]. Passive transfer of the $\mathrm{BnAb}$ VRC01 is currently under evaluation for its potential to protect humans from HIV-1 (NCT02716675 and NCT02568215).

Coincident with this exciting work on BnAbs, there is a growing body of literature on the importance of Fcmediated functions of HIV-1 antibodies. Fc-mediated

\footnotetext{
*Correspondence: mattp@unimelb.edu.au; skent@unimelb.edu.au ${ }^{1}$ Department of Microbiology and Immunology, The University of Melbourne, at the Peter Doherty Institute for Infection and Immunity, Victoria, Australia

Full list of author information is available at the end of the article
}

functions of non-neutralizing antibodies appeared to be important in the modest protective efficacy of the RV144 HIV-1 vaccine regimen [13-15]. Fc-mediated functions of HIV-1 antibodies generally correlate with slow HIV-1 disease progression and can force viral escape [16-19].

More potent Fc-mediated functions of BnAbs should theoretically enhance their efficacy and there is some evidence that this is the case [20]. This might be particularly important when HIV-1 is transmitted in the context of infected cells, which may partially evade neutralization by BnAbs. This review summarizes data on the importance of Fc-mediated functions of BnAbs.

\section{Diversity of Fc-mediated functionality of isolated BnAbs}

The breadth of viral recognition and much of the antiviral potency of BnAbs is derived from the recognition of key viral epitopes by $\mathrm{BnAb}$ paratopes that prevent the infection of cellular targets through viral neutralization. Importantly, BnAbs have the potential to mediate a diverse array of additional non-neutralizing functions through ligation of the Fc portion of the antigen-bound antibody by components of the complement system or 
effector cells expressing Fc receptors (FcR). Indeed, HIV1-infected cells bound by BnAbs can be targeted by FcRexpressing effector cells, such as natural killer (NK) cells, for elimination by antibody-dependent cellular cytotoxicity (ADCC) [21-23]. As well as cytolysis of infected cells opsonized by BnAbs, effector cells recognizing BnAbcoated target cells can become stimulated to produce soluble factors, such as beta chemokines, that can inhibit viral spread. The combination of ADCC, neutralization and effector cell derived soluble inhibitors of viral spread has been termed antibody-dependent cell-mediated viral inhibition (ADCVI), and this response can be mediated by BnAbs [24, 25]. Additionally, FcR-expressing phagocytic effector cells, such as monocytes, can eliminate $\mathrm{BnAb}$-coated virions through an antibody-dependent uptake process, termed antibody-dependent phagocytosis (ADP) [26]. Lastly, infected cells coated by BnAbs can be targeted for elimination by the process of antibodydependent complement-mediated lysis (ADCML) [22]. It should be noted that further diversity in these processes is introduced by the differential responsiveness of effector cells at different stages of ontogeny and differentiation, as well as polymorphisms in FcR that adjust effector cell responsiveness to antibody-coated target cells. Lastly, diversity in Fc-dependent non-neutralizing functions is driven by the differential capacity of individual BnAbs to trigger these functions.

Much research into the Fc-dependent functions of BnAbs has focused on ADCC. Indeed, several independent studies have assessed the capacity of panels of antibodies (including BnAbs) to trigger NK cell-mediated ADCC of target cells infected with diverse viral isolates [21-23]. Although these studies have revealed that the observed ADCC is highly dependent on the antibody and virus combination studied, several general characteristics of ADCC have been elucidated. It has now been demonstrated that: (1) the degree of antibody binding to target cells correlates with the susceptibility of the target cell to ADCC [21-23]; (2) the ability of the antibody to neutralize a virus isolate associates with the capacity of the antibody to trigger ADCC of target cells infected with the same isolate [21, 23]; and (3) combinations of antibodies trigger potent ADCC [21, 22]. It should be noted that exceptions to these generalizations have been reported. In particular, it has been reported that the $2 \mathrm{G} 12$ and $2 \mathrm{~F} 5$ BnAbs trigger poor ADCC despite binding to infected cells [23]. Although the reasons for the reduced ADCC function of these two BnAbs have not been determined, roles for NK cell accessibility to 2F5 and the Fab swapped variable region of $2 \mathrm{G} 12$ have been proposed [23]. Importantly, some investigators have observed ADCC by $2 \mathrm{~F} 5$ recognizing infected target cells [27], and 2G12 in monomeric and dimeric formats has been reported to induce
ADCC $[28,29]$. This suggests that the ADCC capacity of some BnAbs is highly context dependent, and this is an area for future research.

In addition to ADCC, recent research has also demonstrated BnAbs to bind to FcRs involved in ADP and to have the capacity to trigger phagocytosis of viral particles. Factors influencing BnAb ADP were recently investigated by Tay et al. [26]. These investigators employed the CD4 binding site specific $\mathrm{CH} 31 \mathrm{BnAb}$ to determine the effect of antibody isotype and IgG subclass on phagocytic activity. Primary monocytes were employed as effector cells and demonstrated to uptake viral particles opsonized by IgG1, monomeric IgA1 and monomeric IgA2 versions of $\mathrm{CH} 31$. Interestingly, IgG1 was a more potent inducer of viral particle uptake than IgA1 or IgA2. Next, the relative capacities of IgG1 and IgG3 to trigger ADP of viral particles by primary monocytes were assessed. The IgG3 version of $\mathrm{CH} 31$ was a more potent inducer of ADP than IgG1. This phenomenon of more potent ADP by IgG3 was shown to not be a result of enhanced antigen binding, and enhanced ADP of IgG3 compared to IgG1 was demonstrated for two additional BnAbs $(\mathrm{CH} 27$ and $\mathrm{CH} 28$ ) and non-broadly neutralizing antibodies directed to different epitopes.

As well as FcR binding, several BnAbs have now been screened for their capacity to trigger lysis of infected cells in a complement-dependent manner [22]. Furthermore, mutants of a CD4 binding site $\mathrm{BnAb}, \mathrm{b} 12$, have been generated to exhibit different patterns of complement binding [30]. Passive immunization of these b12 mutants in macaques prior to mucosal SHIV challenge revealed no role for complement in b12-conferred protection from infection [5]. It remains undetermined if this observation extends to BnAbs other than b12. The capacity of a panel of antibodies (including BnAbs) to trigger ADCML of HIV-1-infected target cells was recently investigated by Mujib et al. [22]. An array of ADCML capacities was noted within the antibody panel. Although not statistically significant, a trend was noted between the level of antibody binding to infected cells and the ADCML observed.

As well as the Fc-dependent functions of BnAbs reviewed above, it is important to highlight additional functional roles of the antibody Fc that might be of significance for BnAb-conferred protection from HIV-1. For instance, interaction of antibody Fc with the neonatal FcR ( FcRn) is important for extending antibody half-life, as well as localizing and sustaining antibody to mucosal sites of HIV-1 exposure [31]. Lastly, an understudied FcFcR interaction is that between antibodies and the inhibitory FcyRIIb. Interaction of immune complexes formed by live-attenuated SIV vaccine-induced antibodies with FcyRIIb expressed in the epithelium associates with 
Table 1 Role for Fc-dependent BnAb functions for protection from cell free virus in vivo

\begin{tabular}{|c|c|c|c|c|}
\hline Aim of study & $\begin{array}{l}\text { BnAb } \\
\text { studied }\end{array}$ & Model & Outcome & References \\
\hline $\begin{array}{l}\text { Compare wild type b12 with b12 versions deficient for } \\
\text { FcR binding and/or complement binding for protection } \\
\text { of macaques from high-dose SHIV challenge }\end{array}$ & b12 & $\begin{array}{l}\text { Macaque high- } \\
\text { dose SHIV }\end{array}$ & $\begin{array}{l}\text { Elimination of the ability of b12 to engage } \\
\text { FcR diminished the ability of the antibody } \\
\text { to protect macaques from high-dose SHIV } \\
\text { challenge }\end{array}$ & {$[5]$} \\
\hline $\begin{array}{l}\text { Compare low doses of wild type b12 and b12 deficient for } \\
\text { FCR binding for protection of macaques from repeated } \\
\text { low-dose SHIV challenge }\end{array}$ & b12 & $\begin{array}{l}\text { Macaque } \\
\text { repeated low- } \\
\text { dose SHIV }\end{array}$ & $\begin{array}{l}\text { More challenges did not result in infection of } \\
\text { animals infused with wild type b12, as com- } \\
\text { pared to animals infused with b12 deficient } \\
\text { in FcR binding }\end{array}$ & {$[35]$} \\
\hline $\begin{array}{l}\text { Assess if low doses of a non-fucosylated version of b12, } \\
\text { with enhanced ADCC potential, are better than wild } \\
\text { type b12 for protecting macaques from repeated low- } \\
\text { dose SHIV challenge }\end{array}$ & b12 & $\begin{array}{l}\text { Macaque } \\
\text { repeated low- } \\
\text { dose SHIV }\end{array}$ & $\begin{array}{l}\text { Non-fucosylated b12 did not provide } \\
\text { enhanced protection from repeated low- } \\
\text { dose SHIV challenge, as compared to wild } \\
\text { type b12 }\end{array}$ & {$[36]$} \\
\hline $\begin{array}{l}\text { Screen panel of BnAbs with enhanced of diminished FcR } \\
\text { binding for ability to block viral entry in a murine model }\end{array}$ & $\begin{array}{l}\text { BnAb } \\
\text { panel }\end{array}$ & $\begin{array}{l}\text { Murine HIV-1 } \\
\text { entry }\end{array}$ & $\begin{array}{l}\text { BnAbs with enhanced FCR binding demon- } \\
\text { strated enhanced in vivo blocking of HIV-1 } \\
\text { entry }\end{array}$ & {$[20]$} \\
\hline $\begin{array}{l}\text { Determine if modifying VRC01 to enhance binding to } \\
\text { FCRn improves the ability of suboptimal doses of the } \\
\text { BnAb to protect against SHIV challenge }\end{array}$ & VRC01 & Macaque SHIV & $\begin{array}{l}\text { Suboptimal doses of VRC01 with enhanced } \\
\text { binding to FcRn protected more macaques } \\
\text { from SHIV challenge than wild type VRC01 }\end{array}$ & {$[31]$} \\
\hline
\end{tabular}

live-attenuated vaccine-conferred protection from infection [32]. It is thought that this interaction prevents/ diminishes the recruitment of target cells for SIV infection to the site of exposure. The importance of FcyRIIb for $\mathrm{BnAb}$ conferred protection from mucosal viral challenges in macaques has not yet been investigated.

\section{Role of Fc-dependent functions in efficacy of BnAbs against cell free virus in vivo}

A collection of studies demonstrate that BnAbs administered passively or through gene transfer using adenoassociated viral vectors protect against in vivo challenge with cell free virus in animal models of HIV-1 infection $[5-8,10,12,20,31,33-36]$. While these studies clearly highlight the prophylactic capacity of BnAbs, only a few of the reports incorporated experiments to assess the potential mechanisms of BnAb-conferred protection (Table 1) $[5,20,31,35,36]$. Such experiments are important to gauge if neutralization function is sufficient, or if BnAbs need to trigger additional non-neutralizing functions through their Fc portions to protect against HIV-1 exposure.

Hessell et al. initially evaluated the involvement of nonneutralizing $\mathrm{Fc}$-dependent functions in BnAb conferred protection from in vivo cell free virus challenge [5]. For this purpose the authors utilized a previously developed panel of variants of the CD4 binding site BnAb, b12 [30]. These variants included the b12 wild type (b12 WT), a version mutated to diminish $\mathrm{F} c \gamma \mathrm{R}$ and complement binding (b12 LALA), and a version only exhibiting diminished complement binding (b12 KA). Each of these b12 variants, or human IgG1 isotype control, were passively administered intravenously to rhesus macaques prior to vaginal challenge with high-dose cell free $\mathrm{SHIV}_{\mathrm{SF162P3}}$. While all four animals receiving the isotype control were infected following challenge, animals receiving b12 WT and b12 KA exhibited similar robust levels of protection from infection (i.e. 8/9 animals protected in each group). Animals receiving the b12 LALA were less likely to be protected from challenge than animals receiving the b12 WT or b12 KA antibodies (i.e. 5/9 animals protected). These results imply that neutralization is often sufficient for protection from cell free virus challenge, but protection is optimized if BnAbs can trigger additional nonneutralizing effector cell functions through effector cells expressing Fc $\gamma$ Rs.

Following their observation of lower efficacy of b12 LALA than b12 WT in protecting against high-dose cell free virus challenge, Hessell et al. evaluated the potential role of non-neutralizing functions of b12 for protection of macaques from repeated low-dose cell free $\mathrm{SHIV}_{\mathrm{SF} 162 \mathrm{P} 3}$ challenge [35]. Animals were injected once weekly with low doses of b12 WT or b12 LALA and challenged twice weekly with low-dose virus. Animals inoculated with either b12 WT or b12 LALA required more challenges prior to becoming infected than animals administered isotype control prior to challenge. Although both b12 WT and b12 LALA provided protection compared to isotype control, protection conferred by b12 LALA appeared suboptimal as compared to b12 WT. Indeed, nearly twice as many challenges did not result in infection for b12 WT animals than b12 LALA animals (i.e. 104 vs. 61). These observations largely reflected the 
relative patterns of protection conferred by b12 WT and b12 LALA following high-dose viral challenge [5].

The major implication of the two studies assessing the relative protective efficacy of b12 variants with different $\mathrm{Fc} \gamma \mathrm{R}$ binding potential is that neutralization is often sufficient for protection from infection with cell free virus. It is possible that neutralization might fail to be sufficient for protection when too large of a number of cells are infected following challenge. In these situations nonneutralizing Fc-dependent functions of BnAbs could be required to purge infected cells through ADCC or eliminate the virions produced by infected cells by ADP. The potential contribution of ADCC to protection conferred by b12 was evaluated by Moldt et al., who compared the relative protection from repeated low-dose SHIV $_{\text {SF162P3 }}$ challenge conferred by b12 WT to a non-fucosylated version of b12 (NFb12) [36]. Despite exhibiting higher binding to human and rhesus macaque FcyRIIIa and mediating higher ADCC of HIV-1-infected cells, the NFb12 antibody did not confer enhanced protection from cell free viral challenge as compared to b12 WT. These results might reflect the importance of Fc-dependent functions other than ADCC in the protection conferred by BnAbs.

Until recently much of the research into the role of non-neutralizing $\mathrm{Fc}$-dependent functions for $\mathrm{BnAb}$-conferred protection from in vivo cell free virus challenge was conducted using the b12 BnAb. Since the isolation of b12 numerous anti-HIV-1 BnAbs have been isolated and demonstrated to exhibit enhanced neutralization breadth and potency [1]. The role of Fc-dependent functions in the protective efficacy of some of these BnAbs has been evaluated in mouse models of HIV-1 entry [20]. Inhibition of HIV-1 entry can be assessed in luciferase reporter mice by infusing adenovirus encoding HIV-1 receptor and co-receptor (i.e. CD4 and CCR5), infusing anti-HIV-1 or control antibodies, challenging with HIV-1 pseudovirus and full-body imaging. Employing this system Bournozos et al. [20] demonstrated that BnAbs with murine IgG2a Fc, which confers preferential binding to activating FcyRs, were better able to inhibit HIV-1 entry than BnAbs expressing wild type murine IgG1 or an IgG1 variant with diminished binding to FcyR. Reliance on Fc-dependent functions for optimal in vivo efficacy was observed for a panel of antibodies, suggesting Fc-dependent functions are important independent of the viral epitope targeted by the antibody. That this observation reflected Fc $\gamma R$ engagement by antibodies is suggested by the absence of differences in efficacy between antibody variants in mice lacking $\mathrm{Fc} \gamma \mathrm{R}$ expression. Lastly, it is important to note that the authors modified their mouse model by engineering mice to express human FcyRs. This allowed an assessment of the role of Fc-dependent functions for BnAbs expressing human Fc in preventing viral entry. Employing wild type $\mathrm{BnAb}$, as well as versions engineered to exhibit deficient or enhanced $\mathrm{Fc} F \mathrm{R}$ binding, the authors observed evidence for a role for human $\mathrm{Fc} / \mathrm{Fc} \gamma \mathrm{R}$ interactions in inhibition of in vivo viral entry. Cumulatively, these observations are largely supportive of the role for $\mathrm{Fc} / \mathrm{Fc} \gamma \mathrm{R}$ interactions in BnAb-conferred protection observed in macaques. The results from the murine experiments suggest that the role for Fc-dependent anti-viral functions of BnAbs for optimal protection extends beyond the b12 BnAb and might be a generalizable phenomenon.

Lastly, it should be noted that in addition to triggering anti-viral effector functions, interactions between BnAbs and FcRs are important for sustaining antibody concentrations and antibody transport. Indeed, antibody binding to the FcRn is important for homeostasis and antibody transport to mucosal surfaces. As such, the VRC01 antibody was recently mutated to enhance binding to the FcRn [31]. The resulting VRC01-LS antibody exhibited increased in vitro transcytosis, a 2.5 -fold longer in vivo serum half-life in rhesus macaques and a tendency to accumulate in macaque rectal tissues through FcRn binding. Lastly, suboptimal concentrations of VRC01-LS provided enhanced protection against rectal $\mathrm{SHIV}_{\mathrm{BaLP} 4}$ challenge, as compared to VRC01 WT (i.e. $7 / 12$ vs. $2 / 12$ animals protected from infection). These results highlight that $\mathrm{Fc} / \mathrm{FcR}_{\mathrm{C}}$ interactions are an important determinant of $\mathrm{BnAb}$-conferred protection, even if the interaction does not directly stimulate anti-viral functions.

\section{Utility of BnAbs for control of cell-cell virus transmission in vitro}

Much evidence highlights the potential utility of BnAbs for preventing HIV-1 infection. A potential caveat for utilizing BnAbs to prevent HIV-1 infection is the presence of cell-associated virus within infectious bodily fluids, such as semen [37]. Cell-associated virus has long been proposed as a mechanism of transmission of HIV-1-the so-called "Trojan Horse" hypothesis [38, 39]. In macaques, cell-associated SIV is highly efficient at initiating infection, more so than cell free virus [40]. In humans, there are limited data based on virus sequencing that cell-associated virus may initiate a proportion of HIV-1 infections [41].

A key component of the "Trojan horse" hypothesis is that cell-associated virus may evade anti-viral immunity [38, 39]. There has been much research into this possibility, particularly with regards to cell-associated virus evading BnAbs. While some publications have reported BnAbs to prevent in vitro cell-to-cell transmission of HIV-1, others have demonstrated a decreased efficacy of BnAbs against cell-associated virus compared to 
cell free virus [42-51]. These divergent results likely reflect the utilization of different in vitro experimental systems. Nevertheless, decreased efficacy a BnAbs against cell-associated virus has been reported in terms of both higher $50 \%$ inhibitory concentrations $\left(\mathrm{IC}_{50}\right)$ and incomplete neutralization [45]. Importantly, the ability of BnAbs to prevent cell-to-cell spread is dependent on the virus/antibody combination [47]. Furthermore, combinations of BnAbs may be more efficient than single antibodies [44].

\section{BnAb control of cell-associated challenge in vivo}

We recently developed a cell-associated SHIV $_{\text {SF162P3 }}$ infection model in pigtail macaques [52]. The model was adapted from a previously published cell-associated SIV model that used splenocytes from infected macaque donors to initiate infection [53]. Passive transfer of the BnAb PGT121 protected 6/6 pigtail macaques from an intravenous cell free $\mathrm{SHIV}_{\mathrm{SF} 162 \mathrm{P} 3}$ challenge but only $3 / 6$ macaques from an intravenous cell-associated SHIV $_{\text {SF162P3 }}$ challenge. However, the lack of efficacy in two macaques challenged with the cell-associated SHIV $_{\text {SF162P3 }}$ appeared due to low levels of BnAb administered. Interestingly, one macaque had no viremia until eight weeks post challenge with cell-associated $\mathrm{SHIV}_{\mathrm{SF} 162 \mathrm{P} 3}$. It appeared that the $\mathrm{SHIV}_{\mathrm{SF} 162 \mathrm{P} 3}$ lay dormant, possibly existing as cell-associated virus in tissues, and only emerged when the passively transferred $\mathrm{BnAb}$ waned to low levels. Whether this anecdote will represent a common mode of evading strategies to control HIV-1 with BnAbs is unknown. We recently suggested that, given the capacity of HIV-1 to remain latent under ART for decades, HIV-1 could remain suppressed by BnAbs for years until the antibodies (whether delivered passively or induced by vaccination) wane to sub therapeutic levels [54]. This has implications for the longterm follow up of BnAb based clinical trials.

\section{The use of BnAbs for HIV-1 therapy and cure: role of Fc-dependent responses}

Following the isolation of first generation BnAbs there was much interest in their potential for therapeutic utilization. In an early study in hu-PBL-SCID mice, Poignard et al. observed limited utility of first generation BnAbs in mice infected with HIV-1 $1_{\text {JR-CSF }}$ or HIV-1 ${ }_{\text {SF162 }}$ [55]. Indeed, monotherapy with the CD4 binding site $\mathrm{BnAb}$, b12, did not significantly decrease plasma viral loads in mice infected with either virus, as compared to control animals. Furthermore, several viral isolates derived from animals treated with b12 developed resistance to the
BnAb. Similarly, treatment of mice infected with HIV$1_{\text {IR-CSF }}$ with a cocktail of BnAbs (i.e. b12, 2G12 and 2F5) achieved unsatisfactory results. Temporary decreases in viral load were noted, but were followed by viral rebound and escape from one or all three BnAbs.

Trials of first generation BnAbs as therapeutics in HIV1-infected humans also revealed transient therapeutic benefits followed by viral escape from BnAb. Trkola et al. administered a BnAb cocktail (i.e. 2G12, 2F5 and 4E10) to eight individuals with chronic HIV-1 infection and six individuals with acute HIV-1 infection one day before cessation of ART [56]. Trial participants received $13 \mathrm{BnAb}$ injections over 11 weeks. Two of eight chronically infected donors exhibited a delay in viral rebound, as compared to historical data of the same individuals undergoing a treatment interruption in the absence of BnAb therapy. The acutely infected BnAb-treated participants exhibited a significant time delay prior to viral rebound as compared to a control group of acutely infected individuals undergoing treatment interruption in the absence of $\mathrm{BnAb}$ treatment (median 8 weeks vs. 3.75 weeks). The therapeutic benefits of the $\mathrm{BnAb}$ cocktail appeared to be primarily driven by $2 \mathrm{G} 12$, as viral rebound was accompanied by resistance to $2 \mathrm{G} 12$ in $12 / 14$ trial participants. Mehandru et al. reported similar results in another trial assessing the therapeutic potential of the BnAb cocktail of 2G12, 2F5 and 4E10 [57]. As observed by Trkola et al. [56], these investigators noted that BnAb therapy slowed viral rebound following treatment interruption, as compared to historical controls. Furthermore, loss of viral control was associated with resistance to $2 \mathrm{G} 12$.

Since these initial trials, numerous BnAbs, with increased potency and breadth compared to first generation BnAbs, have been isolated from HIV-1-infected individuals [1]. The isolation of next generation BnAbs has reinvigorated interest in utilizing BnAbs as therapeutics for HIV-1 infection. Assessment of the therapeutic potential of next generation BnAbs in humanized mouse models suggested monotherapy to be inefficient, transiently controlling viremia before the development of viral resistance to BnAbs [58]. Combination therapy with five BnAbs, however, controlled viremia and did not result in viral resistance to BnAbs. Another study demonstrated that single BnAbs were sufficient to control viremia in a proportion of humanized mice, if viral replication was first controlled by $\mathrm{ART}$ and $\mathrm{BnAb}$ administrations were initiated prior to cessation of ART [59]. Studies in non-human primates have revealed that both combination therapy and monotherapy with BnAbs can control SHIV replication, but monotherapy can lead to 
the development of viral escape mutants $[2,11]$. Furthermore, therapeutic administration of BnAbs to macaques during acute SHIV infection might facilitate the development of autologous antiviral immunity, thus conferring prolonged control of viral replication [9].

In addition to animal studies, next generation BnAbs have also been screened as therapeutics in HIV-1-infected humans $[3,4,60]$. Monotherapy with 3BNC117 and 10-1074 results in transient control of viremia, and 3BNC117 can delay viral rebound following treatment interruption. As noted in animal studies, viral resistance to BnAbs can develop in humans undergoing monotherapy.

As well as data highlighting the capacity of BnAbs to control viremia, several studies using murine models, as well as modelling of data from a human clinical trial, suggest a role for FcyRs in the therapeutic benefits conferred by BnAbs. A role for BnAb interactions with Fc $\gamma \mathrm{R}$ for controlling viremia in infected animals was demonstrated by Bournazos et al. [20]. Humanized mice infected with HIV-1 were treated with a cocktail of BnAbs (i.e. 3BNC117, PG16 and 10-1074) modified either to not interact with $\mathrm{Fc} \gamma \mathrm{R}$ $\left(F c R^{\text {null }}\right)$ or to exhibit enhanced binding to activating $F c \gamma R$. A quicker and sustained control of viremia was observed in animals treated with the antibody cocktail containing antibodies designed to more strongly interact with activating Fc $\gamma R$. Halper-Stromberg et al. demonstrated that treatment of HIV-1-infected humanized mice with a BnAb cocktail (i.e. 10-1074, PG16 and 3BNC117) 4 days post infection reduced the establishment of a latent reservoir, as exhibited by a lack of viral rebound in a proportion of animals after waning of therapeutic BnAbs [61]. A rendition of this experiment using $\mathrm{FcR}_{\mathrm{C}}{ }^{\text {null }}$ versions of the BnAbs suggested a role for $\mathrm{F} c \gamma \mathrm{R}$ interactions in the observed interference with the establishment of a latent reservoir. Significantly more mice had rebounded viremia by 44 days post treatment with $\mathrm{FcR}^{\text {null }}$ versions of the BnAbs than those treated with wild type BnAbs capable of interacting with FcyR. Lastly, Lu et al. assessed the rate of viral load decline in HIV-1-infected humans treated with 3BNC117 [62]. Modelling suggested that the rate of decline in viremia was too rapid to be explained by neutralization of free virus alone. Indeed, the analysis suggested that non-neutralizing antibody effector functions, such as those involved in eliminating infected cells, were involved in the therapeutic benefits conferred by the antibody. Furthermore, the ability of BnAbs to eliminate human cells infected with the HIV-1 $1_{\mathrm{YU} 2}$ laboratory strain or isolates derived from HIV-1-infected patients was demonstrated in vivo in mice. The elimination of infected cells was demonstrated to be dependent on Fc $\gamma \mathrm{R}$-mediated recognition of antibody, as infected cells were not eliminated by $\mathrm{FcR}^{\text {null }} \mathrm{BnAbs}$ and in vivo blocking of $\mathrm{Fc \gamma}$ Rs prevented the elimination of infected cells.

\section{Diversity of Effector cells, FcyRs and antibody isotypes: potential influence on BnAb efficacy}

While the $\mathrm{BnAb}$ paratope dictates neutralization breadth and potency, accumulating evidence indicates that Fcdependent functions might be required for BnAbs to optimally protect from infection, suppress viral load and/ or clear infected cells $[5,20,61,62]$. These Fc-dependent functions might include ADCC, ADP, complement activation, effector cell release of cytokines, chemokines or enzymes, inhibition of transcytosis and mucus trapping. An antibody's Fc functional capacity can be modulated through multiple small biophysical differences of the $\mathrm{Fc}$ region [63], including the isotype (e.g., IgG, IgA, IgM, IgE, IgD), subclass (e.g., IgG1-4, IgA1, IgA2) [64], allotype $[65,66]$ and glycosylation of the Fc heavy chain $[67,68]$.

In humans, there are three distinct classes of $\mathrm{Fc} \gamma$ receptors: Fc $\gamma$ RI, Fc $\gamma$ RII (Fc $\gamma$ RIIa, Fc $\gamma$ RIIb, and Fc $\gamma$ RIIc), and Fc $\gamma$ RIII (FcyRIIIa and FcyRIIIb), which bind to different IgG subclasses with varying affinity, and can cause either activation or inhibition of the effector cell [64]. These Fc $\gamma$ Rs are expressed on a wide variety of innate immune cells including NK cells, monocytes, macrophages, dendritic cells, eosinophils, basophils and neutrophils. NK cells almost exclusively express the activating Fc $\gamma$ RIIIa and are the effector cells most commonly associated with ADCC [69]. Macrophages, neutrophils, eosinophils, basophils and dendritic cells all express a more diverse range of Fc $\gamma$ Rs on their surfaces (both activating and inhibitory) and can mediate various effector functions, including ADCC, phagocytosis and trogocytosis (i.e., the exchange of cellular membrane fragments between effector and target cells) [70-72].

Human Fc $\gamma$ Rs are diverse. A range of $F c \gamma R$ polymorphisms have been identified, some of which have greater Fc binding affinity and are associated with enhanced Fc effector function capacity. For example, Fc $\gamma$ RIIa has two common polymorphisms-H131 and R131. The FcyRIIa H131 polymorphism, which is commonly associated with enhanced ADP, is also related to HIV-1 disease progression status [73, 74]. The Fc $\gamma$ RIIIa is also known to exhibit polymorphisms at position 158-V158 and F158. The high affinity FcyRIIIa V158 polymorphism, is associated with enhanced ADCC functionality and with better outcomes for cancer monoclonal therapeutics [75, 76]. Surprisingly, the Fc $\gamma$ RIIIa V158 polymorphism might associate with HIV-1 disease progression [77] and associates with the risk of infection in recipients of the VAX004 vaccine [78].

While many factors can contribute to the Fc-dependent functions of antibodies, several studies have generated HIV-1-specific BnAbs with modified capacities to bind $\mathrm{Fc} \gamma \mathrm{Rs}$ and mediate Fc-dependent functions [5, 25, 36]. The aim of such studies is to gain an understanding of how to improve BnAb-conferred protection from 
infection. While abrogation of the Fc-dependent activity of $\mathrm{BnAb}$ b12 through introduction of the LALA mutation decreased the protective efficacy of the BnAb [5], a nonfucosylated version of b12, which exhibited an enhanced ability to bind to FcyRIIIa and trigger ADCC, did not confer any additional protection from repeated low-dose viral challenge [36]. These data suggest that engagement of FcyRIIIa and the triggering of ADCC activity are likely not essential to achieve in vivo BnAb-conferred protection from viral challenge. Alternatively, BnAbs that trigger a wide range of Fc-dependent functions or 'polyfunctional' Fc activity may be optimal. Indeed, several studies suggest that polyfunctional non-neutralizing Fcdependent functions of HIV-1 binding antibodies can contribute to enhanced viral control and protection from infection [79-82]. Furthermore, the presence of antibodies with Fc polyfunctionality may contribute to the development of BnAbs. Richardson et al. recently observed that individuals that develop BnAbs have higher Fc polyfunctionality and increased subclass diversity [83].

It is important to note that studies have also assessed the effect of modifying the isotypes of BnAbs, especially to IgA, with varying results [84-88]. Isotype switching of 2F5 from IgG1 to IgA2 improved epitope affinity and improved inhibition of HIV-1 transcytosis [84]. In contrast, other studies have reported 2F5 IgA or 2F5 IgM variants to provide inferior protection against HIV-1 compared to $2 \mathrm{~F} 5 \operatorname{IgG}[85,86]$. Indeed, $2 \mathrm{~F} 5 \mathrm{IgM}$ failed to inhibit HIV-1 transcytosis [85], while 2F5 IgA failed to neutralize HIV-1 infection of PBMC [86]. In contrast, 2 F5 IgG protected against HIV-1 infection in vitro and intravenous administration of 2F5 IgG protected macaques from intravaginal viral challenge [86]. Importantly, intravenous administration of 2F5 Fab exhibited no protection, emphasizing the importance of the Fc region of the $2 \mathrm{~F} 5 \mathrm{BnAb}$ for protection. An additional study modified the V3 neutralizing antibody HGN194 from IgG1 to dimeric IgA1 and dimeric IgA2. The resulting antibodies exhibited similar neutralization potencies, but HGN194 dimeric IgA1 provided the best protection in vivo against intrarectal viral challenge. Protection was correlated with in vitro measurements of inhibition of viral transcytosis and virion capture [87]. Lastly, neutralizing CH31 IgG antibodies exhibited enhanced protection against intrarectal viral challenge in macaques compared to monomeric, dimeric or secretory IgA2 variants [88]. Clearly, these studies indicate that the isotype of BnAbs can contribute significantly to protection from mucosal viral challenge, but the contribution of isotype might be epitope specific and too few studies have been conducted to determine how the antibody isotype contributes mechanistically to protection. Similar to IgG, IgA can engage its $F c \alpha$ receptor that is present on the surfaces of monocytes, macrophages and neutrophils to mediate phagocytosis, respiratory burst, and the release of various cytokines and inflammatory mediators [89]. The potential of $\mathrm{Fc} / \mathrm{FcR}$ interactions between IgA and $\mathrm{Fc} \alpha$ receptor is an area of research that has not yet been fully explored in terms of its potential for combatting HIV -1 .

\section{Potential importance of diverse human NK cell functionality on BnAb efficacy}

In addition to polymorphisms in Fc $\gamma$ Rs, several additional variables might potentially impact the ability of effector cells to utilize BnAbs to mediate Fc-dependent functions. NK cells and the impact of the processes of education and differentiation on their functional potential best represent this.

Diversity in the capacity of NK cells to respond to stimuli is introduced through the process of NK cell education [90]. During the education process NK cells scan the self-environment for constitutively expressed ligands to their activating and inhibitory receptors. The receptors involved in this process include activating and inhibitory killer immunoglobulin-like receptors (KIR), which recognize classical major histocompatibility complex class I (MHC-I or HLA-I) molecules [91], and the inhibitory NKG2A receptor, which recognizes the nonclassical HLA-E [92]. In general, education tunes the potential responsiveness of an NK cell in a manner that maintains self-tolerance, conferring functional capacity to cells expressing inhibitory receptors that recognize self-ligands [93-95] and reducing the functional capacity of cells expressing activating receptors that recognize self-ligands [96]. Several studies have now demonstrated that education determines the responsiveness of NK cells to direct stimulation with HLA-I-devoid target cells [93, 94], as well as FcyR-dependent stimulation of NK cells with antibody-coated target cells $[93,95]$.

The role of NK cell education in determining Fcdependent NK cell functions via anti-HIV-1 antibodies has been investigated using HIV-1 envelope coated target cells and polyclonal antibodies derived from patients [97100]. Most of these studies have evaluated the role of education in anti-HIV-1 Fc-dependent NK cell responses by focusing on single education-competent receptor/ligand combinations, such as KIR3DL1/HLA-Bw4 or KIR2DL1/ HLA-C2. The highlighted studies have pointed to higher levels of antibody-dependent activation in NK cells educated through the studied receptor than in an autologous NK cell population containing both non-educated cells and cells educated through other inhibitory receptors. Isitman et al. compared anti-HIV-1 ADCC mediated by PBMC from individuals with NK cells educated through KIR3DL1/HLA-Bw4 and individuals with NK cells lacking education through KIR3DL1/HLA-Bw4 [101]. No 
differences in ADCC were noted between the two groups, leading the investigators to suggest that NK cell education may not be important for determining anti-HIV-1 ADCC capacity. Alternatively, it is possible that NK cells educated through inhibitory receptor/ligand combinations other than KIR3DL1/HLA-Bw4 conferred compensatory NK cell education in the individuals lacking this receptor/ ligand combination. We recently attempted to evaluate the relative contributions of educated and non-educated NK cells within PBMC to anti-HIV-1 ADCC [99]. Briefly, PBMC were stained with fluorochrome-conjugated antibodies to identify cells expressing inhibitory receptors that would educate NK cells, given the donor's HLA-I profile. Stained cells were FACs sorted as a population enriched for educated NK cells (i.e. education ${ }^{+}$PBMC) and unstained cells were sorted as a population lacking educated NK cells (i.e. education ${ }^{-}$PBMC). Utilizing cell numbers reflecting the frequency of each population of cells within total PBMC, we evaluated the relative ability of each cell population to kill gp120-coated target cells in the presence of anti-HIV-1 antibodies. We observed robust ADCC mediated by total PBMC that was recaptured by the sorted education ${ }^{+}$PBMC. In contrast, the sorted education ${ }^{-}$PBMC mediated little-to-no ADCC, and were significantly less cytotoxic than either the whole PBMC or the education ${ }^{+}$PBMC population.

While our data imply that educated NK cells are the primary mediators of anti-HIV-1 ADCC within PBMC, it is important to note that these data were collected using gp120-coated target cells and with polyclonal antibody mixtures. Future experiments are needed to determine if education has a similar impact on the capacity of NK cells to utilize BnAbs to mediate anti-HIV-1 ADCC. Furthermore, it would be ideal to conduct these experiments with autologous HIV-1-infected target cells, which present viral envelope in physiological conformations and amounts. The implementation of autologous infected cells will also address the role of autologous HLA-I in inhibiting anti-HIV-1 ADCC, and how downregulation of HLA-I by HIV-1 nef influences the ability of self-HLAI to inhibit anti-HIV-1 ADCC [102].

In addition to education, the relative responsiveness of an NK cell to antibody-dependent stimulation is determined by the stage of differentiation of the cell. NK cells differentiate in a defined pattern, proceeding from CD56 ${ }^{\text {bright }}$ to $\mathrm{CD} 56^{\mathrm{dim}}$ before gaining expression of the CD57 differentiation marker [103]. Throughout this process NK cells gain expression of KIRs and FcyRIIIa and become more cytotoxic. Additionally, differentiated CD56 ${ }^{\mathrm{dim}} \mathrm{CD} 57^{+} \mathrm{NK}$ cells exhibit more robust responses through FcyRIIIa following stimulation with anti-receptor antibody or anti-viral antibody-coated target cells expressing HIV-1 antigens [100, 104].
Importantly, viral infections appear to influence the NK cell differentiation process. Indeed, individuals infected with human cytomegalovirus (HCMV) exhibit expansions of differentiated $\mathrm{CD} 56^{\mathrm{dim}} \mathrm{CD} 57^{+}$ NK cells that also express the activating NKG2C receptor, which recognizes the non-classical HLA-E molecule $[92,105]$. These NK cells exhibit robust function through FcyRIIIa [106]. Furthermore, these differentiated NK cells degranulate following ligation of NKG2C [105]. Interestingly, CD $56^{\mathrm{dim}} \mathrm{CD} 57^{+} \mathrm{NKG} 2 \mathrm{C}^{+} \mathrm{NK}$ cells have been noted to occur in HIV-1-infected individuals in a HCMV-dependent manner [107]. The frequency of these cells in HIV-1-infected donors, however, appears to be exaggerated compared to HCMV-infected HIV-1-uninfected donors. Further research is required to determine the anti-HIV-1 antibody-dependent functions of $\mathrm{CD} 56{ }^{\mathrm{dim}} \mathrm{CD} 57^{+} \mathrm{NKG} 2 \mathrm{C}^{+} \mathrm{NK}$ cells. It will be interesting to determine if these cells can confer enhanced anti-viral benefits in individuals receiving BnAbs for the purposes of therapy or cure.

Lastly, the ability of NK cells to mediate Fc-dependent functions is influenced by virus-induced alterations on target cells. Much has been published on the ability of HIV-1 nef and vpu to downregulate CD4 on infected cells, prevent exposure of CD4-induced epitopes on viral envelope and facilitate the evasion of ADCC mediated by polyclonal patient-derived ADCC antibodies that predominantly recognize CD4-induced envelope epitopes $[108,109]$. This phenomenon is less of a problem for BnAb-mediated ADCC, as BnAbs tend to recognize HIV-1 envelope in its native CD4-unbound trimeric state. In addition to downregulating CD4, HIV-1 nef can downregulate the expression of ligands for the activating NKG2D NK cell receptor, which can serve as a co-receptor for anti-HIV-1 ADCC [110-112]. Furthermore, HIV-1 vpu can downregulate cellular tetherin, which plays an essential role is concentrating virus at the cellular membrane. Downregulation of tetherin decreases the amount of viral antigen available on the surface of infected cells and is a means of evading anti-HIV-1 ADCC [113]. The potential for HIV-1 accessory proteins to influence ADCC readouts highlights the importance of carefully selecting viruses and assays that most closely portray the in vivo situation in which the antibody in question will be immersed [112, 114].

\section{Conclusions}

The weight of data supports the contention that Fcmediated functions of BnAbs are important to their efficacy in preventing HIV-1 and controlling viremia. This contribution is likely to be even more important in 
the context of exposure to cell-associated virus, where virus may evade neutralization by BnAbs. Newer generation BnAbs have higher potency and are potential tools for preventing and controlling HIV-1 infection. Additional work characterizing the in vivo importance of Fc-mediated functions of newer generation BnAbs is needed.

\section{Authors' contributions}

All authors contributed to the writing of the manuscript. All authors approved the manuscript for final publication.

\begin{abstract}
Author details
${ }^{1}$ Department of Microbiology and Immunology, The University of Melbourne, at the Peter Doherty Institute for Infection and Immunity, Victoria, Australia.

${ }^{2}$ ARC Centre of Excellence in Convergent Bio-Nano Science and Technology, The University of Melbourne, Victoria, Australia. ${ }^{3}$ Melbourne Sexual Health Centre, Alfred Hospital, Monash University Central Clinical School, Victoria, Australia.
\end{abstract}

\section{Competing interests}

The authors declare that they have no competing interests.

\section{Availability of data and material \\ Not applicable.}

\section{Consent for publication}

Not applicable.

\section{Ethics approval and consent to participate}

Not applicable.

\section{Funding}

Australian National Health and Medical Research Council Grant \# 1052979.

\section{Publisher's Note}

Springer Nature remains neutral with regard to jurisdictional claims in published maps and institutional affiliations.

Received: 14 May 2018 Accepted: 9 August 2018

Published online: 22 August 2018

\section{References}

1. McCoy LE, Burton DR. Identification and specificity of broadly neutralizing antibodies against HIV. Immunol Rev. 2017;275:11-20.

2. Barouch DH, Whitney JB, Moldt B, Klein F, Oliveira TY, Liu J, Stephenson KE, Chang HW, Shekhar K, Gupta S, et al. Therapeutic efficacy of potent neutralizing HIV-1-specific monoclonal antibodies in SHIV-infected rhesus monkeys. Nature. 2013;503:224-8.

3. Caskey M, Klein F, Lorenzi JC, Seaman MS, West AP Jr, Buckley N, Kremer G, Nogueira L, Braunschweig M, Scheid JF, et al. Viraemia suppressed in HIV-1-infected humans by broadly neutralizing antibody 3BNC117. Nature. 2015;522:487-91.

4. Caskey M, Schoofs T, Gruell H, Settler A, Karagounis T, Kreider EF, Murrell B, Pfeifer N, Nogueira L, Oliveira TY, et al. Antibody 10-1074 suppresses viremia in HIV-1-infected individuals. Nat Med. 2017;23:185-91.

5. Hessell AJ, Hangartner L, Hunter M, Havenith CE, Beurskens FJ, Bakker JM, Lanigan CM, Landucci G, Forthal DN, Parren PW, et al. Fc receptor but not complement binding is important in antibody protection against HIV. Nature. 2007:449:101-4.

6. Hessell AJ, Rakasz EG, Poignard P, Hangartner L, Landucci G, Forthal DN, Koff WC, Watkins DI, Burton DR. Broadly neutralizing human anti-HIV antibody 2 G12 is effective in protection against mucosal SHIV challenge even at low serum neutralizing titers. PLoS Pathog. 2009:5:e1000433.
7. Moldt B, Rakasz EG, Schultz N, Chan-Hui PY, Swiderek K, Weisgrau KL, Piaskowski SM, Bergman Z, Watkins DI, Poignard P, Burton DR. Highly potent HIV-specific antibody neutralization in vitro translates into effective protection against mucosal SHIV challenge in vivo. Proc Natl Acad Sci U S A. 2012;109:18921-5.

8. Moog C, Dereuddre-Bosquet N, Teillaud JL, Biedma ME, Holl V, Van Ham G, Heyndrickx L, Van Dorsselaer A, Katinger D, Vcelar B, et al. Protective effect of vaginal application of neutralizing and nonneutralizing inhibitory antibodies against vaginal SHIV challenge in macaques. Mucosal Immunol. 2014;7:46-56.

9. Nishimura Y, Gautam R, Chun TW, Sadjadpour R, Foulds KE, Shingai M, Klein F, Gazumyan A, Golijanin J, Donaldson M, et al. Early antibody therapy can induce long-lasting immunity to SHIV. Nature. 2017;543:559-63.

10. Parren PW, Marx PA, Hessell AJ, Luckay A, Harouse J, Cheng-Mayer C, Moore JP, Burton DR. Antibody protects macaques against vaginal challenge with a pathogenic R5 simian/human immunodeficiency virus at serum levels giving complete neutralization in vitro. J Virol. 2001;75:8340-7.

11. Shingai M, Nishimura $Y$, Klein F, Mouquet $H$, Donau OK, Plishka R, Buckler-White A, Seaman M, Piatak M Jr, Lifson JD, et al. Antibodymediated immunotherapy of macaques chronically infected with SHIV suppresses viraemia. Nature. 2013;503:277-80.

12. Veazey RS, Shattock RJ, Pope M, Kirijan JC, Jones J, Hu Q, Ketas T, Marx PA, Klasse PJ, Burton DR, Moore JP. Prevention of virus transmission to macaque monkeys by a vaginally applied monoclonal antibody to HIV-1 gp 120. Nat Med. 2003;9:343-6.

13. Haynes BF, Gilbert PB, McElrath MJ, Zolla-Pazner S, Tomaras GD, Alam SM, Evans DT, Montefiori DC, Karnasuta C, Sutthent R, et al. Immunecorrelates analysis of an HIV-1 vaccine efficacy trial. N Engl J Med. 2012;366:1275-86.

14. Rerks-Ngarm S, Pitisuttithum P, Nitayaphan S, Kaewkungwal J, Chiu J, Paris R, Premsri N, Namwat C, de Souza M, Adams E, et al. Vaccination with ALVAC and AIDSVAX to prevent HIV-1 infection in Thailand. N Engl J Med. 2009:361:2209-20.

15. Tomaras GD, Ferrari G, Shen X, Alam SM, Liao HX, Pollara J, Bonsignori M, Moody MA, Fong $Y$, Chen $X$, et al. Vaccine-induced plasma IgA specific for the $\mathrm{C} 1$ region of the HIV-1 envelope blocks binding and effector function of IgG. Proc Natl Acad Sci U S A. 2013;1 10:9019-24.

16. Chung AW, Isitman G, Navis M, Kramski M, Center RJ, Kent SJ, Stratov I. Immune escape from HIV-specific antibody-dependent cellular cytotoxicity (ADCC) pressure. Proc Natl Acad Sci U S A. 2011:108:7505-10.

17. Horwitz JA, Bar-On Y, Lu CL, Fera D, Lockhart AAK, Lorenzi JCC, Nogueira L, Golijanin J, Scheid JF, Seaman MS, et al. Non-neutralizing antibodies alter the course of HIV-1 infection in vivo. Cell. 2017;170:637-648.e10.

18. Lambotte O, Ferrari G, Moog C, Yates NL, Liao HX, Parks RJ, Hicks CB, Owzar K, Tomaras GD, Montefiori DC, et al. Heterogeneous neutralizing antibody and antibody-dependent cell cytotoxicity responses in HIV-1 elite controllers. AIDS. 2009;23:897-906.

19. Wren LH, Chung AW, Isitman G, Kelleher AD, Parsons MS, Amin J, Cooper DA, Asc investigators, Stratov I, Navis M, Kent SJ. Specific antibody-dependent cellular cytotoxicity responses associated with slow progression of HIV infection. Immunology. 2013;138:116-123

20. Bournazos S, Klein F, Pietzsch J, Seaman MS, Nussenzweig MC, Ravetch JV. Broadly neutralizing anti-HIV-1 antibodies require Fc effector functions for in vivo activity. Cell. 2014;158:1243-53.

21. Bruel T, Guivel-Benhassine F, Amraoui S, Malbec M, Richard L, Bourdic K, Donahue DA, Lorin V, Casartelli N, Noel N, et al. Elimination of HIV-1-infected cells by broadly neutralizing antibodies. Nat Commun. 2016;7:10844

22. Mujib S, Liu J, Rahman A, Schwartz JA, Bonner P, Yue FY, Ostrowski MA. Comprehensive cross-clade characterization of antibody-mediated recognition, complement-mediated lysis, and cell-mediated cytotoxicity of HIV-1 envelope-specific antibodies toward eradication of the HIV-1 reservoir. J Virol. 2017;91:e00634-17.

23. von Bredow B, Arias JF, Heyer LN, Moldt B, Le K, Robinson JE, ZollaPazner S, Burton DR, Evans DT. Comparison of Antibody-dependent cell-mediated cytotoxicity and virus neutralization by HIV-1 Env-specific monoclonal antibodies. J Virol. 2016;90:6127-39.

24. Forthal DN, Landucci G, Daar ES. Antibody from patients with acute human immunodeficiency virus (HIV) infection inhibits primary strains 
of HIV type 1 in the presence of natural-killer effector cells. J Virol. 2001;75:6953-61.

25. Moldt B, Schultz N, Dunlop DC, Alpert MD, Harvey JD, Evans DT, Poignard P, Hessell AJ, Burton DR. A panel of $\lg G 1$ b12 variants with selectively diminished or enhanced affinity for Fcgamma receptors to define the role of effector functions in protection against HIV. J Virol. 2011;85:10572-81.

26. Tay MZ, Liu P, Williams LD, McRaven MD, Sawant S, Gurley TC, Xu TT, Dennison SM, Liao HX, Chenine AL, et al. Antibody-mediated internalization of infectious HIV-1 virions differs among antibody isotypes and subclasses. PLoS Pathog. 2016;12:e1005817.

27. Tudor $D$, Bomsel M. The broadly neutralizing HIV-1 IgG $2 F 5$ elicits gp41-specific antibody-dependent cell cytotoxicity in a FcgammaRldependent manner. AIDS. 2011;25:751-9.

28. Klein JS, Webster A, Gnanapragasam PN, Galimidi RP, Bjorkman PJ. A dimeric form of the HIV-1 antibody 2G12 elicits potent antibodydependent cellular cytotoxicity. AIDS. 2010;24:1633-40

29. Trkola A, Purtscher M, Muster T, Ballaun C, Buchacher A, Sullivan N, Srinivasan K, Sodroski J, Moore JP, Katinger H. Human monoclonal antibody 2G12 defines a distinctive neutralization epitope on the gp120 glycoprotein of human immunodeficiency virus type 1. J Virol. 1996;70:1100-8.

30. Hezareh M, Hessell AJ, Jensen RC, van de Winkel JG, Parren PW. Effector function activities of a panel of mutants of a broadly neutralizing antibody against human immunodeficiency virus type 1. J Virol. 2001;75:12161-8.

31. Ko SY, Pegu A, Rudicell RS, Yang ZY, Joyce MG, Chen X, Wang K, Bao $S$, Kraemer TD, Rath T, et al. Enhanced neonatal Fc receptor function improves protection against primate SHIV infection. Nature. 2014:514:642-5.

32. Smith AJ, Wietgrefe SW, Shang L, Reilly CS, Southern PJ, Perkey KE, Duan L, Kohler H, Muller S, Robinson J, et al. Live simian immunodeficiency virus vaccine correlate of protection: immune complex-inhibitory Fc receptor interactions that reduce target cell availability. J Immunol. 2014:193:3126-33.

33. Gardner MR, Kattenhorn LM, Kondur HR, von Schaewen M, Dorfman T, Chiang JJ, Haworth KG, Decker JM, Alpert MD, Bailey CC, et al. AAVexpressed eCD4-Ig provides durable protection from multiple SHIV challenges. Nature. 2015;519:87-91.

34. Saunders KO, Wang L, Joyce MG, Yang ZY, Balazs AB, Cheng C, Ko SY, Kong WP, Rudicell RS, Georgiev IS, et al. Broadly neutralizing human immunodeficiency virus type 1 antibody gene transfer protects nonhuman primates from mucosal simian-human immunodeficiency virus infection. J Virol. 2015;89:8334-45.

35. Hessell AJ, Poignard P, Hunter M, Hangartner L, Tehrani DM, Bleeker WK, Parren PW, Marx PA, Burton DR. Effective, low-titer antibody protection against low-dose repeated mucosal SHIV challenge in macaques. Nat Med. 2009;15:951-4.

36. Moldt B, Shibata-Koyama M, Rakasz EG, Schultz N, Kanda Y, Dunlop DC, Finstad SL, Jin C, Landucci G, Alpert MD, et al. A nonfucosylated variant of the anti-HIV-1 monoclonal antibody b12 has enhanced FcgammaRlIla-mediated antiviral activity in vitro but does not improve protection against mucosal SHIV challenge in macaques. J Virol. 2012;86:6189-96.

37. Ho DD, Schooley RT, Rota TR, Kaplan JC, Flynn T, Salahuddin SZ, Gonda MA, Hirsch MS. HTLV-III in the semen and blood of a healthy homosexual man. Science. 1984;226:451-3.

38. Anderson DJ, Politch JA, Nadolski AM, Blaskewicz CD, Pudney J, Mayer KH. Targeting Trojan Horse leukocytes for HIV prevention. AIDS. 2010;24:163-87.

39. Anderson DJ, Yunis EJ. "Trojan Horse" leukocytes in AIDS. N Engl J Med. 1983;309:984-5

40. Kolodkin-Gal D, Hulot SL, Korioth-Schmitz B, Gombos RB, Zheng Y, Owuor J, Lifton MA, Ayeni C, Najarian RM, Yeh WW, et al. Efficiency of cell-free and cell-associated virus in mucosal transmission of human immunodeficiency virus type 1 and simian immunodeficiency virus. J Virol. 2013:87:13589-97.

41. Zhu T, Wang N, Carr A, Nam DS, Moor-Jankowski R, Cooper DA, Ho DD. Genetic characterization of human immunodeficiency virus type 1 in blood and genital secretions: evidence for viral compartmentalization and selection during sexual transmission. J Virol. 1996;70:3098-107.
42. Abela IA, Berlinger L, Schanz M, Reynell L, Gunthard HF, Rusert P, Trkola A. Cell-cell transmission enables HIV-1 to evade inhibition by potent CD4bs directed antibodies. PLoS Pathog. 2012;8:e1002634.

43. Duncan CJ, Williams JP, Schiffner T, Gartner K, Ochsenbauer C, Kappes J, Russell RA, Frater J, Sattentau QJ. High-multiplicity HIV-1 infection and neutralizing antibody evasion mediated by the macrophage-T cell virological synapse. J Virol. 2014;88:2025-34.

44. Gombos RB, Kolodkin-Gal D, Eslamizar L, Owuor JO, Mazzola E, Gonzalez AM, Korioth-Schmitz B, Gelman RS, Montefiori DC, Haynes BF, Schmitz JE. Inhibitory effect of individual or combinations of broadly neutralizing antibodies and antiviral reagents against cell-free and cellto-cell HIV-1 transmission. J Virol. 2015;89:7813-28.

45. Li H, Zony C, Chen P, Chen BK. Reduced Potency and incomplete neutralization of broadly neutralizing antibodies against cell-tocell transmission of HIV-1 with transmitted founder Envs. J Virol. 2017:91:e02425-16

46. Malbec M, Porrot F, Rua R, Horwitz J, Klein F, Halper-Stromberg A, Scheid JF, Eden C, Mouquet H, Nussenzweig MC, Schwartz O. Broadly neutralizing antibodies that inhibit HIV-1 cell to cell transmission. J Exp Med. 2013;210:2813-21.

47. Reh L, Magnus C, Schanz M, Weber J, Uhr T, Rusert P, Trkola A. Capacity of broadly neutralizing antibodies to inhibit HIV-1 cell-cell transmission is strain- and epitope-dependent. PLoS Pathog. 2015;11:e1004966.

48. Schiffner T, Sattentau QJ, Duncan CJ. Cell-to-cell spread of HIV-1 and evasion of neutralizing antibodies. Vaccine. 2013;31:5789-97.

49. Martin N, Welsch S, Jolly C, Briggs JA, Vaux D, Sattentau QJ. Virological synapse-mediated spread of human immunodeficiency virus type 1 between T cells is sensitive to entry inhibition. JVirol. 2010;84:3516-27.

50. Massanella M, Puigdomenech I, Cabrera C, Fernandez-Figueras MT, Aucher A, Gaibelet G, Hudrisier D, Garcia E, Bofill M, Clotet B, Blanco J. Antigp41 antibodies fail to block early events of virological synapses but inhibit HIV spread between T cells. AIDS. 2009;23:183-8.

51. McCoy LE, Groppelli E, Blanchetot C, de Haard H, Verrips T, Rutten L, Weiss RA, Jolly C. Neutralisation of HIV-1 cell-cell spread by human and Ilama antibodies. Retrovirology. 2014;11:83.

52. Parsons MS, Lloyd SB, Lee WS, Kristensen AB, Amarasena T, Center RJ, Keele BF, Lifson JD, LaBranche CC, Montefiori D, et al. Partial efficacy of a broadly neutralizing antibody against cell-associated SHIV infection. Sci Transl Med. 2017;9:eaaf1483.

53. Salle B, Brochard P, Bourry O, Mannioui A, Andrieu T, Prevot S, DejucqRainsford N, Dereuddre-Bosquet N, Le Grand R. Infection of macaques after vaginal exposure to cell-associated simian immunodeficiency virus. J Infect Dis. 2010;202:337-44.

54. Parsons MS, Cromer D, Davenport MP, Kent SJ. HIV reactivation after partial protection by neutralizing antibodies. Trends Immunol. 2018:39:359-66.

55. Poignard P, Sabbe R, Picchio GR, Wang M, Gulizia RJ, Katinger H, Parren PW, Mosier DE, Burton DR. Neutralizing antibodies have limited effects on the control of established HIV-1 infection in vivo. Immunity. 1999;10:431-8.

56. Trkola A, Kuster H, Rusert P, Joos B, Fischer M, Leemann C, Manrique A, Huber M, Rehr M, Oxenius A, et al. Delay of HIV-1 rebound after cessation of antiretroviral therapy through passive transfer of human neutralizing antibodies. Nat Med. 2005;11:615-22.

57. Mehandru S, Vcelar B, Wrin T, Stiegler G, Joos B, Mohri H, Boden D, Galovich J, Tenner-Racz K, Racz P, et al. Adjunctive passive immunotherapy in human immunodeficiency virus type 1-infected individuals treated with antiviral therapy during acute and early infection. J Virol. 2007:81:11016-31.

58. Klein F, Halper-Stromberg A, Horwitz JA, Gruell H, Scheid JF, Bournazos S, Mouquet H, Spatz LA, Diskin R, Abadir A, et al. HIV therapy by a combination of broadly neutralizing antibodies in humanized mice. Nature. 2012;492:118-22.

59. Horwitz JA, Halper-Stromberg A, Mouquet H, Gitlin AD, Tretiakova A, Eisenreich TR, Malbec M, Gravemann S, Billerbeck E, Dorner M, et al. HIV-1 suppression and durable control by combining single broadly neutralizing antibodies and antiretroviral drugs in humanized mice. Proc Natl Acad Sci U S A. 2013;110:16538-43.

60. Scheid JF, Horwitz JA, Bar-On Y, Kreider EF, Lu CL, Lorenzi JC, Feldmann A, Braunschweig M, Nogueira L, Oliveira T, et al. HIV-1 antibody 
3BNC117 suppresses viral rebound in humans during treatment interruption. Nature. 2016;535:556-60.

61. Halper-Stromberg A, Lu CL, Klein F, Horwitz JA, Bournazos S, Nogueira L, Eisenreich TR, Liu C, Gazumyan A, Schaefer U, et al. Broadly neutralizing antibodies and viral inducers decrease rebound from HIV-1 latent reservoirs in humanized mice. Cell. 2014;158:989-99.

62. Lu CL, Murakowski DK, Bournazos S, Schoofs T, Sarkar D, Halper-Stromberg A, Horwitz JA, Nogueira L, Golijanin J, Gazumyan A, et al. Enhanced clearance of HIV-1-infected cells by broadly neutralizing antibodies against HIV-1 in vivo. Science. 2016;352:1001-4.

63. Chung AW, Alter G. Dissecting the antibody constant region protective immune parameters in HIV infection. Future Virol. 2014;9:397-414.

64. Hogarth PM, Pietersz GA. Fc receptor-targeted therapies for the treatment of inflammation, cancer and beyond. Nat Rev Drug Discov. 2012;11:311-31.

65. Moraru M, Black LE, Muntasell A, Portero F, Lopez-Botet M, Reyburn $H T$, Pandey JP, Vilches C. NK cell and Ig interplay in defense against herpes simplex virus type 1: epistatic interaction of CD16A and IgG1 allotypes of variable affinities modulates antibody-dependent cellular cytotoxicity and susceptibility to clinical reactivation. J Immunol. 2015;195:1676-84.

66. Vidarsson G, Dekkers G, Rispens T. IgG subclasses and allotypes: from structure to effector functions. Front Immunol. 2014;5:520.

67. Shields RL, Lai J, Keck R, O'Connell LY, Hong K, Meng YG, Weikert SH, Presta LG. Lack of fucose on human IgG1 N-linked oligosaccharide improves binding to human Fcgamma RIII and antibody-dependent cellular toxicity. J Biol Chem. 2002;277:26733-40.

68. Chung AW, Crispin M, Pritchard L, Robinson H, Gorny MK, Yu X, BaileyKellogg C, Ackerman ME, Scanlan C, Zolla-Pazner S, Alter G. Identification of antibody glycosylation structures that predict monoclonal antibody Fc-effector function. AIDS. 2014;28:2523-30.

69. Ahmad A, Menezes J. Antibody-dependent cellular cytotoxicity in HIV infections. Faseb J. 1996;10:258-66.

70. Kramski M, Schorcht A, Johnston AP, Lichtfuss GF, Jegaskanda S, De Rose R, Stratov I, Kelleher AD, French MA, Center RJ, et al. Role of monocytes in mediating HIV-specific antibody-dependent cellular cytotoxicity. J Immunol Methods. 2012;384:51-61.

71. Worley MJ, Fei K, Lopez-Denman AJ, Kelleher AD, Kent SJ, Chung AW. Neutrophils mediate HIV-specific antibody-dependent phagocytosis and ADCC. J Immunol Methods. 2018;457:41-52.

72. Tjiam MC, Sariputra L, Armitage JD, Taylor JP, Kelleher AD, Tan DB, Lee S, Fernandez S, French MA. Control of early HIV-1 infection associates with plasmacytoid dendritic cell-reactive opsonophagocytic IgG antibodies to HIV-1 p24. AIDS. 2016;30:2757-65.

73. Forthal DN, Landucci G, Bream J, Jacobson LP, Phan TB, Montoya B. FcgammaRlla genotype predicts progression of HIV infection. J Immunol. 2007;179:7916-23.

74. Sanders LA, Feldman RG, Voorhorst-Ogink MM, de Haas M, Rijkers GT, Capel PJ, Zegers BJ, van de Winkel JG. Human immunoglobulin $\mathrm{G}(\mathrm{lgG})$ Fc receptor IIA (CD32) polymorphism and IgG2-mediated bacterial phagocytosis by neutrophils. Infect Immun. 1995;63:73-81.

75. Wang W, Erbe AK, Hank JA, Morris ZS, Sondel PM. NK cell-mediated antibody-dependent cellular cytotoxicity in cancer immunotherapy. Front Immunol. 2015;6:368.

76. Cartron G, Dacheux L, Salles G, Solal-Celigny P, Bardos P, Colombat P, Watier $\mathrm{H}$. Therapeutic activity of humanized anti-CD20 monoclonal antibody and polymorphism in IgG Fc receptor FcgammaRllla gene. Blood. 2002;99:754-8.

77. Poonia B, Kijak GH, Pauza CD. High affinity allele for the gene of FCGR3A is risk factor for HIV infection and progression. PLOS ONE. 2010;5:e15562.

78. Forthal DN, Gabriel EE, Wang A, Landucci G, Phan TB. Association of Fcgamma receptor Illa genotype with the rate of HIV infection after gp120 vaccination. Blood. 2012;120:2836-42.

79. Ackerman ME, Mikhailova A, Brown EP, Dowell KG, Walker BD, BaileyKellogg C, Suscovich TJ, Alter G. Polyfunctional HIV-specific antibody responses are associated with spontaneous HIV control. PLoS Pathog. 2016;12:e1005315.

80. Chung AW, Ghebremichael M, Robinson H, Brown E, Choi I, Lane S, Dugast AS, Schoen MK, Rolland M, Suscovich TJ, et al. Polyfunctional
Fc-effector profiles mediated by $\lg G$ subclass selection distinguish RV144 and VAX003 vaccines. Sci Transl Med. 2014;6:228ra38.

81. Chung AW, Kumar MP, Arnold KB, Yu WH, Schoen MK, Dunphy LJ, Suscovich TJ, Frahm N, Linde C, Mahan AE, et al. Dissecting polyclonal vaccine-induced humoral immunity against HIV using systems serology. Cell. 2015;163:988-98.

82. Barouch DH, Alter G, Broge T, Linde C, Ackerman ME, Brown EP, Borducchi EN, Smith KM, Nkolola JP, Liu J, et al. Protective efficacy of adenovirus-protein vaccines against SIV challenges in rhesus monkeys. Science. 2015;349:320-4.

83. Richardson SI, Chung AW, Natarajan H, Mabvakure B, Mkhize NN, Garrett N, Abdool Karim S, Moore PL, Ackerman ME, Alter G, Morris L. HIV-specific Fc effector function early in infection predicts the development of broadly neutralizing antibodies. PLoS Pathog. 2018;14:e1006987.

84. Tudor D, Yu H, Maupetit J, Drillet AS, Bouceba T, Schwartz-Cornil I, Lopalco L, Tuffery P, Bomsel M. Isotype modulates epitope specificity, affinity, and antiviral activities of anti-HIV-1 human broadly neutralizing 2F5 antibody. Proc Natl Acad Sci U S A. 2012;109:12680-5.

85. Shen R, Drelichman ER, Bimczok D, Ochsenbauer C, Kappes JC, Cannon JA, Tudor D, Bomsel M, Smythies LE, Smith PD. GP41specific antibody blocks cell-free HIV type 1 transcytosis through human rectal mucosa and model colonic epithelium. J Immunol. 2010;184:3648-55.

86. Klein K, Veazey RS, Warrier R, Hraber P, Doyle-Meyers LA, Buffa V, Liao $H X$, Haynes BF, Shaw GM, Shattock RJ. Neutralizing lgG at the portal of infection mediates protection against vaginal simian/human immunodeficiency virus challenge. JVirol. 2013;87:11604-16.

87. Watkins JD, Sholukh AM, Mukhtar MM, Siddappa NB, Lakhashe SK, Kim M, Reinherz EL, Gupta S, Forthal DN, Sattentau QJ, et al. Anti-HIV IgA isotypes: differential virion capture and inhibition of transcytosis are linked to prevention of mucosal R5 SHIV transmission. AIDS. 2013;27:F13-20.

88. Astronomo RD, Santra S, Ballweber-Fleming L, Westerberg KG, Mach L, Hensley-McBain T, Sutherland L, Mildenberg B, Morton G, Yates NL, et al. Neutralization Takes precedence over lgG or IgA Isotype-related functions in mucosal HIV-1 antibody-mediated protection. EBioMedicine. 2016;14:97-111.

89. Lopez E, Shattock R, Kent SJ, Chung AW. The multi-faceted nature of immunoglobulin A and its complex role in HIV. AIDS Res Hum Retroviruses. 2018. https://doi.org/10.1089/AID.2018.0099.

90. Boudreau JE, Hsu KC. Natural killer cell education and the response to infection and cancer therapy: stay tuned. Trends Immunol. 2018;39:222-39.

91. Williams AP, Bateman AR, Khakoo SI. Hanging in the balance. KIR and their role in disease. Mol Interv. 2005;5:226-40.

92. Braud VM, Allan DS, O'Callaghan CA, Soderstrom K, D'Andrea A, Ogg GS, Lazetic S, Young NT, Bell Jl, Phillips JH, et al. HLA-E binds to natural killer cell receptors CD94/NKG2A, B and C. Nature. 1998;391:795-9.

93. Anfossi N, Andre P, Guia S, Falk CS, Roetynck S, Stewart CA, Breso V, Frassati C, Reviron D, Middleton D, et al. Human NK cell education by inhibitory receptors for MHC class I. Immunity. 2006;25:331-42.

94. Kim S, Sunwoo JB, Yang L, Choi T, Song YJ, French AR, Vlahiotis A, Piccirillo JF, Cella M, Colonna M, et al. HLA alleles determine differences in human natural killer cell responsiveness and potency. Proc Natl Acad Sci U S A. 2008;105:3053-8.

95. Parsons MS, Zipperlen K, Gallant M, Grant M. Killer cell immunoglobulin-like receptor 3DL1 licenses CD16-mediated effector functions of natural killer cells. J Leukoc Biol. 2010;88:905-12.

96. Fauriat C, Ivarsson MA, Ljunggren HG, Malmberg KJ, Michaelsson J. Education of human natural killer cells by activating killer cell immunoglobulin-like receptors. Blood. 2010;115:1166-74.

97. Gooneratne SL, Center RJ, Kent SJ, Parsons MS. Functional advantage of educated KIR2DL1(+) natural killer cells for anti-HIV-1 antibodydependent activation. Clin Exp Immunol. 2016;184:101-9.

98. Gooneratne SL, Richard J, Lee WS, Finzi A, Kent SJ, Parsons MS. Slaying the Trojan horse: natural killer cells exhibit robust anti-HIV-1 antibodydependent activation and cytolysis against allogeneic T cells. J Virol. 2015:89:97-109.

99. Kristensen AB, Kent SJ, Parsons MS. Contribution of NK cell education to both direct and anti-HIV-1 antibody-dependent NK cell functions. Virol. 2018:92:e02146-17. 
100. Parsons MS, Loh L, Gooneratne S, Center RJ, Kent SJ. Role of education and differentiation in determining the potential of natural killer cells to respond to antibody-dependent stimulation. AIDS. 2014;28:2781-6.

101. Isitman G, Lisovsky I, Tremblay-McLean A, Parsons MS, Shoukry NH, Wainberg MA, Bruneau J, Bernard NF. Natural killer cell education does not affect the magnitude of granzyme B delivery to target cells by antibody-dependent cellular cytotoxicity. AIDS. 2015;29:1433-43.

102. Cohen GB, Gandhi RT, Davis DM, Mandelboim O, Chen BK, Strominger $J$, Baltimore D. The selective downregulation of class I major histocompatibility complex proteins by HIV-1 protects HIV-infected cells from NK cells. Immunity. 1999;10:661-71.

103. Solana R, Tarazona R, Gayoso I, Lesur O, Dupuis G, Fulop T. Innate immunosenescence: effect of aging on cells and receptors of the innate immune system in humans. Semin Immunol. 2012;24:331-41.

104. Lopez-Verges S, Milush JM, Pandey S, York VA, Arakawa-Hoyt J, Pircher $\mathrm{H}$, Norris PJ, Nixon DF, Lanier LL. CD57 defines a functionally distinct population of mature NK cells in the human CD56dimCD16 + NK-cell subset. Blood. 2010;116:3865-74.

105. Lopez-Verges S, Milush JM, Schwartz BS, Pando MJ, Jarjoura J, York VA, Houchins JP, Miller S, Kang SM, Norris PJ, et al. Expansion of a unique CD57(+)NKG2Chi natural killer cell subset during acute human cytomegalovirus infection. Proc Natl Acad Sci U S A. 2011;108:14725-32.

106. Wu Z, Sinzger C, Frascaroli G, Reichel J, Bayer C, Wang L, Schirmbeck R, Mertens T. Human cytomegalovirus-induced NKG2C(hi) CD57(hi) natural killer cells are effectors dependent on humoral antiviral immunity. J Virol. 2013;87:7717-25.

107. Heath J, Newhook N, Comeau E, Gallant M, Fudge N, Grant M. NKG2C(+)CD57(+) natural killer cell expansion parallels cytomegalovirus-specific CD8(+) T cell evolution towards senescence. J Immunol Res. 2016;2016:7470124.
108. Veillette M, Coutu M, Richard J, Batraville LA, Dagher O, Bernard N, Tremblay C, Kaufmann DE, Roger M, Finzi A. The HIV-1 gp120 CD4-bound conformation is preferentially targeted by antibody-dependent cellular cytotoxicity-mediating antibodies in sera from HIV-1-infected individuals. J Virol. 2015;89:545-51.

109. Veillette M, Richard J, Pazgier M, Lewis GK, Parsons MS, Finzi A. Role of HIV-1 envelope glycoproteins conformation and accessory proteins on ADCC responses. Curr HIV Res. 2016;14:9-23.

110. Alsahafi N, Richard J, Prevost J, Coutu M, Brassard N, Parsons MS, Kaufmann DE, Brockman M, Finzi A. Impaired downregulation of NKG2D ligands by Nef proteins from elite controllers sensitizes HIV1-infected cells to antibody-dependent cellular cytotoxicity. J Virol. 2017;91:e00109-17.

111. Parsons MS, Richard J, Lee WS, Vanderven H, Grant MD, Finzi A, Kent SJ. NKG2D acts as a co-receptor for natural killer cell-mediated anti-HIV-1 antibody-dependent cellular cytotoxicity. AIDS Res Hum Retroviruses. 2016;32:1089-96.

112. Prevost J, Richard J, Medjahed H, Alexander A, Jones J, Kappes JC, Ochsenbauer C, Finzi A. Incomplete downregulation of CD4 expression affects HIV-1 Env conformation and ADCC responses. J Virol. 2018;92:e00484-18.

113. Arias JF, Heyer LN, von Bredow B, Weisgrau KL, Moldt B, Burton DR, Rakasz EG, Evans DT. Tetherin antagonism by Vpu protects HIV-infected cells from antibody-dependent cell-mediated cytotoxicity. Proc Natl Acad Sci U S A. 2014;111:6425-30.

114. Richard J, Prevost J, Baxter AE, von Bredow B, Ding S, Medjahed H, Delgado GG, Brassard N, Sturzel CM, Kirchhoff F, et al. Uninfected bystander cells impact the measurement of HIV-specific antibody-dependent cellular cytotoxicity responses. MBio. 2018;9:e00358-18.
Ready to submit your research? Choose BMC and benefit from:

- fast, convenient online submission

- thorough peer review by experienced researchers in your field

- rapid publication on acceptance

- support for research data, including large and complex data types

- gold Open Access which fosters wider collaboration and increased citations

- maximum visibility for your research: over 100M website views per year

At BMC, research is always in progress.

Learn more biomedcentral.com/submissions 